\title{
EXCESS PROFITS TAXATION AND THE TAXPAYER
}

\author{
Grorge Douglas*
}

Excess profits taxation goes hand in hand with warfare.

It need not be stressed that war requires great sums of money. As the Marshal de Trivulce said when Louis XIV asked him what he needed to make war-"Money, more money, and always money." Governments tap every available source of revenue in times of stress; what is more logical than a special levy on profits considered to be derived either directly or indirectly from the war effort.

Moral considerations in establishing excess profits taxation are also very great; in fact, they tend to dwarf the revenue aspect in most wartime discussions. In setting up an excess profits tax the emphasis is on "taking the profits out of war." The record has been generally one of hasty enactment, followed by revision in more or less substantial decree.

The record of World War I illustrates the popularity of the excess profits tax idea. Denmark and Sweden started the ball rolling in I9I5 when they aimed a tax at the huge profits made on the shipment of goods into Germany. Within a year's time, seventeen countries had excess profits taxes on the books. Significantly, all these countries dropped this form of taxation from their fiscal systems when the war period terminated.

\section{World War I Experience}

Sacrifice and patriotism dominate the entire nation when we take up arms. Such things as imperfections in a tax system are relatively unimportant and rightly so. Most of the authoritative findings about the actual workings of World War I excess profits taxation in the United States had to await the Armistice, although some comment was made earlier.

Generally, the voice of authority was extremely critical. Secretaries of the Treasury McAdoo, Glass and Houston recommended repeal. Mr. McAdoo stated in I918 to the House Ways and Meáns Committee: ${ }^{1}$

The excess-profits tax must rest upon the wholly indefensible notion that it is a function of taxation to bring all profits down to one level with relation to the amount of capital invested, and to deprive industry, foresight and sagacity of their fruits.

* Technical Adviser since 1935 to the Committee on Government Finance of the National Association of Manufacturers and director of the Association's activities and publications in the fields of government finance and taxation. Author of various articles on taxation, public debt, and government cxpenditures.

${ }^{1}$ Hearings before the House Ways and Means Committee on the Revenue Act of 1918,65 th Cong., $2 \mathrm{~d}$ Sess. (x9r8) pt. I, p. I5. 
In his annual report as Secretary of the Treasury for the fiscal year ending June 30, I919, Carter Glass, now the distinguished Senator from Virginia, declared:2

The Treasury's objections to the excess profits tax even as a war expedient (in contradistinction to a war-profits tax) have been repeatedly voiced before the committees of the Congress. Still more objectionable is the operation of the excess profits tax in peacetime. It encourages wasteful expenditure, puts a premium on overcapitalization and a penalty on brains, energy and enterprise, discourages new ventures, and confirms old ventures in their monopolies.

Secretary David F. Houston in the Treasury Department report for the fiscal year I920 declared: ${ }^{3}$

The reason for the repeal of the excess profits tax should be convincing even to those who on grounds of theory or general political philosophy are in favor of taxes of this nature. The tax does not attain in practice the theoretical end at which it aims. ... It is exceedingly complex in its application and difficult of administration, despite the fact that it is limited to one class of business concerns-corporations. Moreover, it is rapidly losing its productivity.

The rgrg report of the Federal Taxation Committee of the National Tax Association proclaims, "A general review of the entire subject of income and excess profits taxes leads us to doubt whether after all, a separate tax on excess profits should be imposed."

Professor T. S. Adams of Yale, speaking with the benefit of his position as Chairman of the Advisory Tax Board of the United States Bureau of Internal Revenue, remarked at the rgrg Conference of the National Tax Association about the World War I excess profits tax then in effect: ${ }^{5}$

As a working measure of taxation, is it fit to survive? The more one knows about the actual operation of this tax, the more cautious he will be in answering this question. The doctrinaire, the taxpayer who knows the circumstances of his own case and no other, the all-wise publicist, with an instant opinion on every important problem ready-Like Postum, in one minute-will answer it lightly. Those who have studied the operation of the tax in thousands of cases, will hesitate to pronounce an opinion. The tax has the merit of being wonderfully productive. It is better than no tax at all; better than bonds to an equivalent amount. But it is decidedly not worth preserving for its own sake.

The taxpayer reaction to World War I excess profits taxation is epitomized in the 1920 report of the Tax Committee of the National Association of Manufacturers which asked ${ }^{\mathbf{B}}$ for repeal on the basis of

... a practical experience with this tax and its effect upon capital, upon labor, upon production, upon price and the enormous expense in preparing tax returns and collecting such a tax....

${ }^{2}$ Rep. Sec'y Treas. (I9I9) 23.

${ }^{3}$ Rep. Sec'y Treas. (I920) 38, 39.

- Nat. Tax Ass'n, Proceedings of the izth Ann. Conf. (I930) 364.

${ }^{5} I d$. at 306 .

'Nat. Ass'n Mfrs., ig20 TAx CoMmitte Report, I5-i6. 
To mention some of the objections, we find the following significant indictments:

(I) Deprives industry of the fruits of its foresight and sagacity.

(2) It burdens brains, ability and energy.

(3) It discourages production.

(4) It penalizes enterprise and ingenuity.

(5) It interferes with the accumulation of industrial capital for the development of business.

(6) It encourages wasteful expenditures.

(7) It puts a premium on overcapitalization and a penalty upon conservative business practice.

(8) It discourages new ventures and confirms old ventures in their monopolies.

This last is particularly significant. Since all industries grow from small beginnings, they need encouragement and resources in the form of profits for future development. But the excess profits tax deprives industry of these encouragements and resources, repressing development and checking enterprise in its very beginning.

\section{The Armament Maker First}

There can be little denial that excess profits taxation originates in a critical atmosphere, if not in an atmosphere of outright hostility. It usually begins with a special levy on the "munition maker"-who is an unpopular figure at the time. The British duty on munition manufacturers profits of $19 \mathrm{I}_{5}$ had its parallel in the United States tax of I9I6 upon net profits from the manufacture of munitions. A general excess profits tax followed in both countries.

The pattern was the same in the present world conflict. Early in 1939 the British imposed a $60 \%$ excess profits tax on armament firms only when it began preparing for the present war. In the fall of 1939 this tax was extended to all companies. In a like manner, the French decree of April 1939 applied high rates only to profits earned by suppliers of materials used for national defense purposes. Five months later all profits were subjected to the tax.

The United States began by restricting profits on government contracts. The Vinson-Trammell Act, ${ }^{7}$ approved March 27, 1934, and amended by the National Defense $\mathrm{Act}^{8}$ of April 3, I939, limited profits on contracts for naval vessels to $10 \%$ and limited profits on contracts for aircraft to $12 \%$. These profit restrictions applied to government contracts in excess of $\$ 10,000$. The Merchant Marine Act of $1936^{9}$ contained profit limitations similar in most respects to those required by the VinsonTrammell Act.

These statutes limiting the profits to be realized on contracts and subcontracts dealing with the manufacture of aircraft, vessels or parts thereof for the government, were suspended generally by Sections 40r and 402 of the Second Revenue Act of 1940 -the so-called first Excess Profits Tax Act.

The report of the Ways and Means Committee of the House of Representatives, submitting the Second Revenue Bill of r940, read in part: $:^{10}$

\footnotetext{
${ }^{7} 48$ STAT. 505, 34 U. S. C. $\$ 496$.

${ }^{9} 49$ STAT. I998, 46 U. S. C. A. \$1155. $\quad{ }_{53}$ Stat. 560 , ro U. S. C. A. \$311, 34, id. \$496.

${ }^{10}$ H. R. REP. No. 2894, 76th Cong., 3d Sess. (1940) 15.
} 
Since the proposed excess profits tax will apply to all corporations, including corporations now subject to the special profit-limiting provisions of the Vinson-Trammell Act, it is felt that such special provisions should not apply while the excess profits tax is in force. Uniformity will thereby be achieved in the treatment for tax purposes of all abnormal profits resulting from the national defense program.

There can be no quarrel with the intent of this last sentence. Certainly the tax payer gives hearty endorsement.

In passing it might be noted that some of the early support for an excess profits tax came from members of Congress and other groups who felt that this type of taxation would reduce pressure for the entry of the United States into the war then being waged in Europe. Bills were drafted and introduced with this purpose in mind.

\section{Basic Attitude of Taxpayers Today}

It has been my privilege to be very close to the thinking of businessmen, large and small, from all sections of the country, during the recent years in which the United States developed the present excess profits tax law.

To the best of my knowledge, no business executive opposes the principle of an excess profits tax which seeks to return to government exorbitant profits arising directly or indirectly from the war effort. This acceptance goes far beyond any public proclamations. Large numbers of industrial leaders have engaged in intricate computations and have considered numerous plans while exploring the possibilities of tax methods which would reach out for war profits.

The point I should like to emphasize is that those who operate the corporate businesses responsible for paying the present excess profits tax have not only accepted the basic principle involved; many of them have worked earnestly to help devise a specific form of tax which would collect the most money in the fairest manner and with the least injury to our economic structure.

It was in such a constructive attitude that the Committee on Government Finance of the National Association of Manufacturers approved ${ }^{11}$ for submission to Congress very early in $x 942$ a proposal for a $90 \%$ tax on excess profits, together with a combined surtax and normal tax of $40 \%$ long before such a drastic excess profits tax rate was offered for consideration by the Treasury Department or any other agency in or out of the government.

I do not want to give the impression that industry-sponsored recommendations have the Alladin's lamp ability to eliminate all problems of taxpayers or that they were designed for such all-protective purposes. More properly, industrialists looked upon the excess profits tax as an imperfect mechanism which under the sharp prod of war necessity must be made to work as well as possible.

Appearing before the Ways and Means Committee in August r940, when consideration was being given to a bill to raise a billion dollars additional revenue yearly to finance the recently initiated emergency national defense program, Carl $N$.

${ }^{11}$ See Hearings before the House Ways and Means Committee on Revenue Revision of r942, 77th Cong,, 2d Sess. (1942) Vol. I, pp. 268-269. 
Osborne, Vice-chairman of the N. A. M. Committee on Government Finance, stated $:^{12}$

Although we favor a carefully drawn excess profits tax as an emergency measure, we wish to point out that the unsound nature of this type of taxation requires that we oppose it as a permanent part of the tax structure.

Livingston W. Houston, Chairman of the 194I N. A. M. Committee on Government Finance, stated to the Ways and Means Committee in May of that year:13

The aim of the excess profits tax should be to reach out for profits arising from defense business, and although we recognize the tremendous difficulties of drafting a law which will achieve this aim with perfection, nevertheless we feel that even a partial achievement is more satisfactory than the complete abandonment of the principle of this law.

A few weeks after Pearl Harbor was bombed, a serious gathering of business executives began an overall study of the revenue needs of government. Out of their deliberations came a program which was put before the Way and Means Committee in March of last year by J. Cheever Cowdin, I942 Chairman of the N. A. M. Committee on Government Finance. Mr. Cowdin said: ${ }^{14}$

We sincerely desire the Congress to draft a bill which will take from industry every last dollar of taxes that can be taken consistent with the tremendous war-production program of the Government....

As concrete evidence of industry's desire to bear additional taxes, we propose that Congress establish, in lieu of present taxes on income of corporations, the following three corporate taxes:

r. A war excess profits tax of 90 percent, applied after;

2. A normal tax upon corporation income at the rate of $x 8$ percent; plus

3. A war tax upon corporation income at the rate of 22 percent.

This would establish a total rate of 40 percent on corporation earnings before application of excess profits taxes.

The foregoing statements should serve to illustrate the development of the taxpayers' basic attitude toward excess profits taxation in the United States beginning with the period of national defense and carrying through to our actual participation in warfare.

\section{The Taxpayers' Problems}

Although there has been general acceptance of the excess profits tax in principle, this should not give the erroneous impression that the life of the taxpayer has been all milk and honey under the various excess profits provisions in effect since 1940. No more complex or confusing language has ever been written into law; and in many phases, the expert has been as baffled as the layman.

\footnotetext{
${ }^{12}$ Hearings before the House Ways and Means Committee on Excess Profits Taxation, 1940, 76th Cong., 3d Sess. (1940) 319.

${ }_{13}$ Hearings before the House Ways and Means Committee on Revenue Revision of 1941, 77th Cong." Ist Sess. (194I) Vol. 2, p. 1651 .

it Hearings, supra note Ir, at 268-269.
} 
The smaller corporation-and this means by far the greater part of the 500,000 business enterprises in this form-is at a relative disadvantage when the law becomes so involved and its administration beset with so many pitfalls. It has been some wonder to me that the rank and file of business apparently has kept up to date with changes in the statutes since in the Second Revenue Act of r 940.

A highly specialized knowledge and competence is required to examine and intelligently apply the law which in many sections is a mass of mumbo-jumbo. Pity the taxpayer who picked up the Revenue Act of 1942 to find Section $740(\mathrm{~g})$ amended as follows:

(g) Component Corporations of Component Corporations.-If a corporation is a component corporation of an acquiring corporation, under subsection (b) or under this subsection, it shall (except for the purposes of section 742 (d) (I) and (2) and section 743 (a) ( 1$),(2)$, and (3)), also be a component corporation of the corporation of which acquiring corporation is a component corporation.

Our lawmakers make no pretense of understanding, or even of reading, the tortuous passages of excess profits taxation which they enact. With all due respect for the difficulties of drafting legislation it seems unbelievable that the Internal Revenue Code cannot be clarified for the benefit of all concerned.

I am reminded of a comment by $\mathrm{E}$. B. White, the oracle of Harpers Magazine. Mr. White had come across a sentence on Form ro40 which included, among other things, three sets of parentheses:

That sentence, above, was obviously written by a lawyer in one of his flights of rhetorical secrecy. There isn't any thought or idea which can't be expressed in a fairly simple declarative sentence, or in a series of fairly simple declarative sentences. The contents of Section $\mathrm{G}$ of Form ro40, I am perfectly sure, could be stated so that the average person could grasp it without suffering dizzy spells. I would state it plainly myself if I could get some lawyer to disentangle it for me first. I'll make my government a proposition: for a five-dollar bill (and costs) I will state it plainly.

\section{Special Problems}

It would take a very exhaustive study to properly examine the innumerable problems of a special nature which were created when the Second Revenue Act of 1940 and subsequent excess profits tax measures went into effect. The practical application of the statutes brought to light many inequalities, uncertainties and ambiguities.

Early in I94I the Committee on Federal Taxation of the American Institute of Accountants submitted recommendations for modification of the abnormality and reorganization sections of the Internal Revenue Code relating to excess profits taxes. The brief outline summary of these recommendations covers three pages of small type.

Later in r94I, after the enactment of a series of amendments to the law, the same Committee of the Institute made additional recommendations for technical and procedural modifications of the excess profits taxation under zI separate headings. Without further detail, it should be evident that the taxpayer has had to face numerous 
technical and procedural problems in the changing pattern of our excess profits tax laws.

\section{The Invested Capital Method}

An integral part of excess profits taxation is the concept of "normal" or base earnings. Two general methods are available for establishing the excess profits tax credit which measures the amount of base earnings over and above which the $90 \%$ excess profits tax applies.

Under the invested capital method the credit is established in the following manner:-

$8 \%$ on the first $\$ 5,000,000$ of invested capital, plus

$7 \%$ on the next $\$ 5,000,000$, plus

$6 \%$ on the next $\$ 190,000,000$ plus

$5 \%$ on invested capital over $\$ 200,000,000$.

This type of schedule definitely discriminates against the larger corporation as such without regard to sound tax principles, and is primarily motivated by the attack upon size and ability which has marked the social and economic reformers of the past decade.

The principle of penalizing a company with large invested capital, as a practical matter, discriminates against the small investor in the larger corporations as compared with both large and small investors in small corporations. Since large corporations usually have substantial numbers of small stockholders, this type of discrimination is of more than academic interest.

\section{The Average Income Method}

The optional method set up in the law allows the taxpayer to compute the excess profits credit either on invested capital or in relation to prior earnings. Corporations in existence before January $1, x 940$, generally may use the average income of the I936-I939 period in setting up their excess profits credit. There are many limitations and qualifications involved in the average earnings method which need not be examined here. The major objections to the present law voiced by taxpayers include:

(I) The average of three out of four years in the base period would establish a more proper base. This would be in line with British practice, where two out of three years of earnings in the base period may be used as a standard.

(2) The arbitrary $5 \%$ reduction in the average earnings of the base period is arbitrary and unsound. In practice the allowance of only $95 \%$ of the average base period net income may not be too serious, but as a matter of principle it has no justification.

\section{Relief Provisions}

The Congress has shown an admirable understanding of the need to protect those companies whose invested capital is so low and whose earnings record is so poor that 
the regular methods of establishing a measure of "normal" earnings would result in serious hardships.

The broad relief provisions in the 1942 law promise to give relief to a great number of companies whose base credits are abnormally low. Under these provisions many companies may establish more adequate yardsticks of normal earnings and diminish their liability for excess profits taxes.

Under Section 722 of the Internal Revenue Code companies are entitled to relief where factors affecting the business resulted in an inadequate standard of normal earnings. Specific consideration is given where:

I. Production was interrupted or diminished in the base period because of unusual and peculiar events.

2. Temporary economic circumstances depressed base period earnings.

3. Conditions prevailing in the industry created a profits cycle differing from the general business cycle, or where the taxpayer's industry did not enjoy a prosperous year, although dependent upon such a good year at irregular intervals.

4. The taxpayer commenced business, changed the operation or management of the business, made a difference in the products or services furnished, changed the ratio of borrowed capital to total capital, or acquired before January I, I940, the assets of a competitor.

It is clear that the burden of proof under the relief sections is upon the taxpayer.

Whether or not the intended relief will be granted depends, in a very important degree, upon the character and the ability of those who administer the tax law. It also involves such basic considerations as a generally sympathetic attitude towards the profit motive and the future of the private enterprise system.

\section{The War Period and the Future}

The drastic nature of excess profits taxation, considered with other heavy taxes upon business concerns during this war period, has resulted in serious strains upon productive enterprise. The impact of these taxes affect:

(I) The ability of companies to retain sufficient earnings in the business after taxes are paid to carry on maximum war production, and

(2) The ability of enterprises to build up sufficient reserves to cushion the effect of transition to peacetime production, to continue operations and to provide jobs in the post-war period.

In order to produce the greatest volume of war material ever turned out by any country in the world, American industry required a comparable amount of financing. With increased production came increased receivables, higher inventories, plant extensions and new machinery required in the war effort. Employment and payrolls jumped tremendously. The funds to meet these production demands had to come from some place or operations would have stopped. 
The banks and the government necessarily supplied the bulk of funds needed to carry out the gigantic war production program. Retained and accumulated earnings also helped finance the expanded war effort in substantial degree, just as they financed the great development of our peacetime industry.

Debt obligations must be met out of what companies have left after taxes-in other words, industry can be made insolvent if taxes get so high that borrowings cannot be repaid.

Under the existing corporation normal tax, surtax and excess profits tax, companies generally will have available after taxes about $3 \%$ out of total business receipts left to keep war materials flowing, pay some dividends to Ir,000,000 stockholders, and have sufficient reserves to reemploy our fighting forces, retool and make new goods after the war.

Definite signs of financial strain are already evident. A study of roo of the larger manufacturing companies released earlier this year by the National City Bank shows that the conversion to war production was accompanied by a substantial increase in inventories and receivables, with a corresponding increase in tax reserves and other liabilities and a consequent decrease in liquidity.

The margin between maximum taxation and overburdening taxation is very slim. The entire nation has a vital stake in seeing that industry has sufficient resources after taxes to do a maximum war production job and to continue operations through the critical days when the war is over.

A cold, factual attitude on excess profits taxation will help maintain peak war production and preserve future solvency. 